\title{
PENILAIAN ASPEK PENGETAHUAN MELALUI JENIS PENILAIAN TES DI TK AL-FADHILLAH KABUPATEN SLEMAN DIY
}

\author{
Raudhah Farah Dilla \\ Universitas Islam Negeri Sunan Kalijaga \\ farahdilla1995@gmail.com
}

\begin{abstract}
ABSTRAC
The goal of education is achievement of attitudes aspects, knowledge aspects, and skills aspects. Knowledge is the most important aspect because positive attitudes will be formed from input and will be expressed in the form of student's performance or student's work. The aim of this research was to find out how the technique of assessing the knowledge test was carried out by one educator of early childhood education in Kabupaten Sleman DIY namely in TK Al-Fadhillah. The method used in this research is observation by collecting data, interview and documentation of a teacher in TK Al-Fadhillah. The results of the study were found that the assessment carried out by TK-Alfadhillah in knowledge aspects used the results of work, notes, pacifiers, scales of development, and conversation. In the type of test appraisal, oral tests which are the most common forms of assessment are carried out in knowing the student's knowledge. The oral test used is not only getting information about the knowledge aspects. But also can improve children's language skills. It means that what is expressed is what the child reflects as far as the knowledge possessed by the child.
\end{abstract}

Keywords: Knowledge Aspects, Test Assessment, Oral Tests

\begin{abstract}
ABSTRAK
Tujuan dari pendidikan ada tiga yaitu ketercapaian pada aspek sikap, aspek pengetahuan, dan aspek keterampilan. Pengetahuan menjadi salah satu yang sangat penting dikarenakan, sikap positif akan terbentuk dari pengetahuan yang didapatkan dan diekspresikan kedalam bentuk unjuk kerja atau hasil karya peserta didik. Tujuan dari penelitian ini ialah untuk mengetahui bagaimana teknik penilaian tes terhadap aspek pengetahuan yang dilakukan oleh salah satu lembaga Pendidikan Anak Usia Dini di Kabupaten Sleman DIY yaitu di TK Al-Fadhillah. Metode yang digunakan dalam penelitian ini yaitu observasi dengan teknik pengumpulan data dengan wawancara dan dokumentasi dari sumber seorang guru TK Al-Fadhillah. Hasil penelitian didapatkan bahwa penilaian yang dilakukan TK-Alfadhillah dalam aspek pengetahuan menggunakan hasil karya, catatan anek dot, skala lingkup perkembangan, dan percakapan. Pada jenis penilaian tes, tes lisan yang menjadi bentuk penilaian yang paling sering dilakukan dalam mengetahui sejauh mana pengetahuan peserta didik. Tes lisan yang digunakan tidak hanya mendapatkan
\end{abstract}


informasi mengenai aspek pengetahun, akan tetapi juga dapat meningkatkan kemampuan bahasa anak. Hal ini dikarenakan setiap apa yang diungkapkan anak mencerminkan sejauh mana pengetahuan yang dimiliki oleh anak.

Kata kunci: Aspek Pengetahuan, Penilaian Tes, Tes Lisan

\section{A. PENDAhuluan}

Penilaian pada pembelajaran anak usia dini mencakup enam program aspek perkembangan. Enam aspek perkembangan tersebut mengarah kepada Kompetensi Dasar sebagai penjabaran dari Kompetensi Inti yang menjadi gambaran pencapaian Standar Tingkat Pencapaian Perkembangan anak diakhir layanan Pendidikan Anak Usia Dini. Kompetensi inti meliputi kompetensi sikap spiritual dan kompetensi sikap sosial (aspek sikap), kompetensi pengetahuan (aspek pengetahuan) dan kompetensi keterampilan (aspek psikomotorik).

Ketiga aspek yang menjadi sasaran akhir dalam penilaian, aspek pengetahuan menjadi hal yang penting menurut PERMENDIKBUD No 146 Tahun 2014, hal ini dikarenakan sikap positif anak akan terbentuk ketika dia memiliki pengetahuan dan mewujudkan pengetahuan itu dalam hasil karya dan unjuk kerja. Artinya, sejauh mana pengetahuan yang dimiliki anak akan tampak ketika melakukan kegiatan yang akan dinilai melalui hasil karya anak atau unjuk kerja. Maka dari itu, perlu kita sebagai pendidik mengevaluasi sejauh mana pengetahuan yang dikuasai guna mengetahui anak mengalami kesulitan belajar atau tidak dan menjadi masukan bagi guru dalam memperbaiki pembelajaran selanjutnya.

Teknik penilaian yang digunakan dalam aspek pengetahuan meliputi tes, non tes dan penguasaan (Setiadi 2016: 170). Tes adalah suatu cara untuk melakukan penilaian yang berbentuk tugas-tugas yang harus dikerjakan siswa. Jawaban yang diberikan peserta didik terhadap pertanyaan atau pemberian tugas akan memberikan informasi terhadap yang mencerminkan kemampuan atau penguasaannya (Sarwiji 2011: 47) 
Terdapat dua jenis tes yaitu tes standar dan tes buatan guru. Tes standar merupakan tes yang dilakukan oleh tenaga ahli professional seperti dokter atau psikolog yang terdiri dari atas tes intelegensi, minat, bakat atau yang lainnya. Hasil tes yang dilakukan oleh dokter atau psikolog tersebut digunakan guru sebagai alat tes untuk lebih mengenal anak. Selanjutnya terdapat tes buatan guru yang dihasilkan oleh guru. Mengembangkan model tes ini, guru harus memperhatikan secara tepat butirbutir pertanyaan yang berkaitan dengan tujuan yang hendak dicapai oleh anak dan juga guru dalam proses pembelajaran. Tes yang dimaksud bisa menggunakan lembar kerja yang langsung dikerjakan oleh anak dan juga berupa lisan dengan bertanya dan anak memberi jawaban. Selanjutnya pada teknik penilaian non tes, dimana alat yang digunakan dalam penilaian non tes aspek pengetahuan yaitu pemberian tugas, percakapan, observasi, catatan aneuk dot, skala penilaian (Anita 2015: 65).

Dari paparan diatas maka observasi ini berupaya mengungkapkan bagaimana teknik penilaian tes terhadap aspek pengetahuan yang dilakukan oleh salah satu lembaga pendidikan anak usia dini di Kabupaten Sleman, DIY yaitu TK AlFadhillah.

\section{B. METODE}

Metode yang digunakan dalam penelitian ini dilakukan dengan observasi, yaitu berusahan mengungkapkan teknik penilaian apa yang digunakan pendidik terhadap penilaian aspek pengetahuan pada peserta didik TK Al-Fadhilah. Pengambilan dan pengumpulan data dilakukan secara kualitatif yaitu dengan cara wawancara dengan responden seorang guru kelas dan dokumentasi berupa dokumen tertulis dari penilaian aspek pengetahuan. Hasil data yang diperoleh didiskusikan kembali bersama guru, guna memperjelas pemahaman peneliti (konfirmasi). Selanjutnya dilakukan analisis beserta pembahasan untuk memperoleh gambaran mengenai proses penilaian yang dilakukan guru dalam memperoleh informasi mengenai sejauh mana pengetahuan pada peserta didik TK Al-Fadhillah. 


\section{PEMBAHASAN}

Hasil wawancara didapatkan, TK Al-Fadhillah hanya menggunakan empat teknik penilaian untuk keseluruhan pencapaian aspek pengetahuan peserta didik. Keempat teknik penilaian yang digunakan TK AL-Fadhillah merupakan metode tes (lisan/tanya jawab/percakapan) dan metode nontes (hasil karya, catatan aneuk dot, dan skala lingkup perkembangan). Teknik penilaian pertama yaitu tes lisan berupa percakapan, penilaian ini dilakukan disetiap akhir pembelajaran guna merefleksikan pengetahuan setelah pembelajaran berlangsung. Kedua yaitu hasil karya anak yang akan dikumpulkan guru kedalam penilaian portofolio. Ketiga, catatan aneukdot, alat penilaian ini digunakan bagi anak yang berperilaku dalam waktu tertentu. Penilaian ini tidak terstruktur karena secara spontan dilakukan dengan hanya mencatat di lembar kertas kecil. Setelah pembelajaran selesai, guru akan memperbaiki catatan tersebut. Keempat yaitu skala penilaian lingkup perkembangan. Penilaian ini dilakukan dengan mencantumkan pencapaian kompetensi dasar setiap harinya dengan skala BB (belum berkembang), MB (mulai berkembang), BSH (berkembang sesuai harapan), BSB (berkembang sangat baik).

Alat penilaian percakapan yang digunakan dalam penilaian aspek pengetahuan anak. Percakapan/tanya jawab ini dilakukan guru dari awal pembelajaran hingga akhir pembelajaran. Diawal pembelajaran guru mengukur pengetahuan anak mengenai tema pada hari tersebut yaitu perlengkapan pekerjaan. Ketika akhir pembelajaran percakapan digunakan untuk melakukan refleksi pembelajaran sesuai dengan tema pada hari tersebut. Refleksi untuk mengetahui sejauh mana pengetahuan anak mengenai pembelajaran hari tersebut, baik berupa mengungkapkan perasaaan, memahami kegunaan perlengkapan pekerjaan, menyebut perlengkapan pembelajaran.

Penilaian aspek pengetahuan menggunakan alat penilaian hasil karya itu dapat dilihat dari kompetensi dasar yang digunakan. Salah satu hasil karya yang dikerjakan anak yaitu menyambung garis putus-putus dengan rapi hingga berbentuk sebuah gambar rumah. Pada kegiatan ini ada kompetensi dasar yang dikembangkan yaitu 
mengenal keaksaraan awal melalui bermain (KD 3.12) dengan aspek perkembangan yang dikembangkan yaitu perkembangan fisik motorik.

Alat penilaian selanjutnya yaitu catatan aneukdot. Penilaian aspek pengetahuan menggunakan catatan anekdot yaitu dengan mencatat apa saja yang berhubungan dengan perilaku anak yang muncul secara tidak biasa. Salah satu perilaku yang tercatat pada hari tersebut yaitu anak mengajak ibunya untuk ikut kekelas dikarenakan buku gambar anak tersebut sudah penuh dan meminta ibunya untuk membelikan yang baru. Pada kegiatan ini ada kompetensi dasar yang muncul yaitu memahami bahasa ekspresif (mengungkapkan bahasa secara verbal dan nonverbal) (KD 3.11) dengan aspek perkembangan yang tampak yaitu perkembangan bahasa dimana indikator pencapaian perkembangan yaitu anak mengungkapkan keinginan, perasaan dan pendapat dengan kalimat sederhana dalam berkomunikasi dengan anak dan orang dewasa.

Alat penilaian terakhir yaitu skala penilaian lingkup perkembangan yang dilakukan setiap harinya. Pada alat penilaian ini tercantum seluruh aspek perkembangan dengan masing-masing kompetensi dasarnya. Penilaian ini memberikan skala berupa BB (belum berkembang), MB (mulai berkembang), BSH (berkembang sesuai harapan), BSB (berkembang sangat baik).

Dari hasil wawancara dengan guru didapatkan informasi bahwa sebenarnya penilaian aspek pengetahuan selalu mendasarkan seluruh aspek perkembangan yang mengacu kepada standar tingkat pencapaian perkembangan anak (STPPA). Standar tingkat pencapaian perkembangan meliputi perkembangan nilai moral agama, perkembangan fisik motorik, perkembangan kognitif, perkembangan bahasa, perkembangan sosio-emosional, dan perkembangan seni. Seluruh aspek perkembangan tersebut merujuk kepada kompetensi dasar sebagai penjabaran dari kompetensi inti, salah satunya yaitu KI-3 sebagai kompetensi pengetahuan. Artinya, penilaian dari aspek perkembangan tersebut mengandung kompetensi dasar dari KI-3. 
Penelitian-penelitian sebelumnya mengemukakan subbahas bahwa penilaian pada seluruh aspek perkembangan memang seharusnya dilakukan pada Pendidikan Anak Usia Dini yang nantinya akan dijadikan sebagai pelaporan hasil akhir mengacu pada aspek pengetahuan, sikap, dan keterampilan.

Sebagaimana penelitian yang dilakukan oleh Eka Damayanti, dkk (2018) dengan judul "Manajemen Penilaian Pendidikan Anak Usia Dini Pada Taman Kanak-Kanak Citra Samata Kabupaten Gowa". Penelitian ini menggambarkan mengenai manajemen penilaian pada pendidikan anak usia dini melalui lima tahap yaitu perencanaan, pelaksanaan atau pencatatan, pengolahan hasil belajar, pengarsipan dan pelaporan. Pada tahap pelaksanaan penilaian di TK Citra Samata, dilakukan berdasarkan seluruh deskripsi pertumbuhan dan perkembangan anak melalui beberapa metode observasi, wawancara/percakapan, penugasan dan unjuk kerja. Dalam observasi terdapat tiga cara yakni catatan harian, catatan anekdot, dan hasil karya. Semua hasil penilaian tersebut akan dimasukkan kedalam tahap pengarsipan dan pelaporan. Tahap pelaporan, akan dijabarkan kompetensi dasar mengenai setiap tahap perkembangan anak. Artinya kompetensi yang dijabarkan berdasarkan kompetensi inti, salah satunya yaitu KI-3.

Penelitian lainnya dilakukan oleh Suyadi (2016) yang berjudul "Perencanaan dan Assesmen Perkembangan Pada Anak Usia Dini". Penelitian ini mendeskripsikan bagaimana guru-guru dilembaga pendidikan anak usia dini pada 55 lembaga di DIY melakukan perencanaan assesmen perkembangan. Informasi yang diperoleh melalui wawancara dan observasi pada kepala sekolah dan guru didapatkan seluruh aspek perkembangan yang tercantum didalam standar tingkat pencapaian perkembangan anak (STPPA) menjadi dasar dalam pembelajaran dengan evaluasi yang dilakukan terhadap indikator-indikator pada aspek perkembangan. 


\subsection{Aspek Pengetahuan}

Ada tiga domain yang sangat penting yang dirumuskan Bloom dkk terhadap tujuan pendidikan yaitu domain kognitif, domain afektif, dan domain psikomotorik yang memiliki tingakatan masing-masing yang akan dijabarkan dalam kata operasional (Arikunto 2015: 130). Domain kognitif berisikan perilaku-perilaku yang merujuk pada intelektualitas seseorang seperti pengetahuan, pengertian dan keterampilan berfikir (Elis 2014: 70). Artinya, segala sesuatu yang berhungan dengan domain kognitif itu berhubungan dengan mental atau otak seseorang. Pada aspek pengetahuan anak usia dini terdapat beberapa kemampuan yang harus dikembangkan menurut PERMENDIKBUD 146 Tahun 2014 yang dikembangkan kedalam kompetensi dasar (KD) sebagai berikut:

Tabel 1. Tabel KD dari KI-3 (Aspek Pengetahuan)

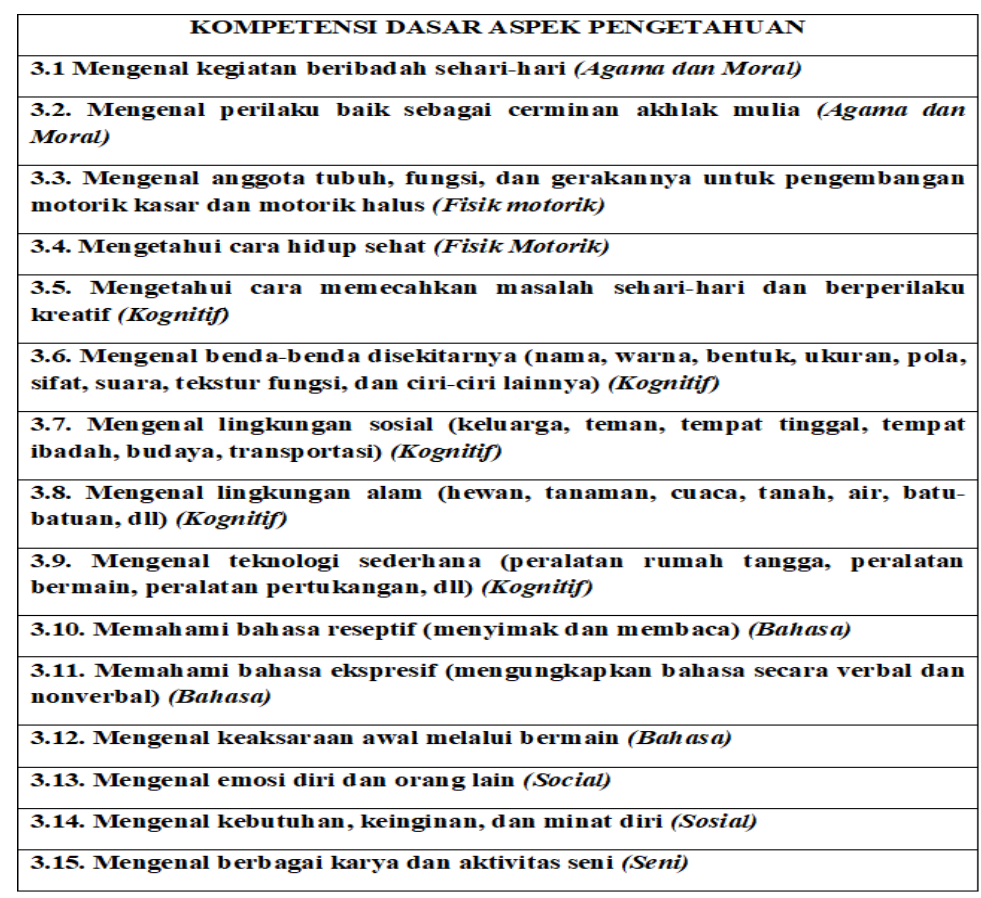

Tabel diatas menjelaskan bahwa seluruh aspek perkembangan anak tetap menjadi dasar utama dalam pengembangan aspek pengetahuan. Pada Taksonomi Bloom domain kognitif atau pengetahuan tersusun dari kemampuan berfikir tingkat 
terendah menuju kemampuan berfikir tingkat paling kompleks yang merupakan suatu kontinus. Tingkatan tersebut ada enam, yaitu mengingat, memahami, mengaplikasikan, menganalisis, mengevaluasi dan menciptakan. Keenam tingkatan tersebut merupakan revisi ranah kognitif Taksonomi Bloom dari tingkatan sebelumnya yaitu pengetahuan, pemahaman, aplikasi, analisis, sintesis, evaluasi (Imam 2012: 99). Mengingat dan memahami merupakan tingkatan kognitif yang paling rendah. Sedangkan mengevaluasi dan menciptakan merupakan tingkatan ranah kognitif yang paling tinggi.

Mengingat, tingkatan ini merupakan kemampuan peserta didik untuk mengingat-ingat/mengenali kembali (recall) terhadap apa yang telah disampaikan pendidik. Peserta didik dapat menyampaikan informasi/pengetahuan sederhana secara verbal atau tulisan. Jadi, ingatan ini bersifat data fakta nyata tanpa ada manipulasi kata-kata. Misalnya, nama-nama tokoh, nama-nama tempat, tanggal lahir Nabi Muhammad, dan sebagainya.

Memahami, kemampuan ini merupakan kemampuan peserta didik memahami, menjabarkan, atau menegaskan informasi yang masuk seperti menafsirkan dengan bahasa sendiri memberi contoh, menjelaskan idea atau konsep, membuat kesimpulan dan melakukan intepretasi sederhana terhadap data/informasi (Kwartolo 2012: 70).

Mengaplikasikan, dalam mengaplikasikan sesuatu, peserta didik memerlukan informasi awal yang dipelajari guna mencapai solusi atau menyelesaikan tugas. Mengaplikasikan menunjuk pada proses kognitif memanfaatkan atau mempergunakan suatu prosedur untuk melaksanakan percobaan atau menyelesaikan permasalahan. Menerapkan berkaitan dengan prosedur (procedural knowledge). Menerapkan meliputi kegiatan menjalankan prosedur dan mengimplementasikannya. Menjalankan prosedur merupakan proses kognitif siswa dalam menyelesaikan masalah dan melaksanakan percobaan dimana siswa sudah mengetahui informasi tersebut dan mampu menetapkan dengan pasti prosedur apa saja yang harus dilakukan. Jika siswa 
tidak mengetahui prosedur apa saja yang harus dilakukan dalam menyelesaikan permasalahan maka siswa diperbolehkan melakukan modifikasi dari prosedur baku yang sudah ditentukan.

Menganalisis, merupakan menyelesaikan suatu permasalahan dengan cara memilah-milah permasalah tersebut dan mencari keterkaitan antaranya. Menganalisis berkaitan dengan proses kognitif memberi atribut dan mengorganisasikan.

Mengevaluasi. evaluasi berkaitan dengan proses kognitif memberikan penilaian berdasarkan kriteria dan standar yang sudah ada. Kriteria atau standar ini bisa ditentukan sendiri oleh peserta didik baik berupa kuantitatif atau kualitatif. Perlu diketahui bahwa tidak semua kegiatan penilaian merupakan dimensi mengevaluasi, namun hampirsemua dimensi proses kognitif memerlukan penilaian.

Mencipta, meletakkan unsur-unsur secara bersamaan untuk membentuk kesatuan yang koheren dan mengarahkan siswa untuk menghasilkan suatu produk baru dengan mengorganisasikan beberapa unsur menjadi bentuk atau pola yang berbeda dari sebelumnya. Menciptakan meliputi menggeneralisasikan dan memproduksi. Menggeneralisasikan merupakan kegiatan mempresentasikan permasalahan dan penemuan alternative hipotesis yang diperlukan. Menggeneralisasikan ini berkaitan dengan berfikir divergen yang merupakan inti dari berfikir kreatif (Kwartolo 2012: 73).

Dari hasil wawancara terhadap guru, tingkatan berfikir yang diterapkan pada anak usia dini berupa mengingat dan memahami. Kegiatan mengingat dan memahami dilakukan guru dengan metode tes lisan/percakapan. Pada tingkatan mengingat, anak mampu mengingat urutan doa ketika pembukaan pembelajaran dan pada tingkat memahami, anak memahami ketika ibu guru memberi salam ia wajib menjawabnya. Setelah itu, guru mengajak anak bercakap-cakap dengan berbagai hal mulai dari kegiatan pembelajaran kemarin sampai kegiatan atau pembahasan tema yang akan dipelajari. 
Sebenarnya, kegiatan yang diberikan guru mengenai tingkatan kognitif mengingat dan memahami pada anak tidak hanya sebatas contoh kegiatan yang disebut diatas. Hal lain yang dapat diperhatikan ialah seperti anak mengingat setiap aturan main yang dipaparkan sebelum kegiatan bermain. Kemudian anak menerapkan ketika kegiatan bermain artinya anak memahami apa yang mejadi peraturan dalam bermain. Sehingga, akan terealisasikan dalam unjuk kerja dan hasil karya anak. Penilaian unjuk kerja yaitu kegiatan mengamati peserta didik dalam melakakukan sesuatu (Hamzah, 2013: 19). Artinya anak yang dapat melakukan unjuk kerja dengan baik, ia mampu mengingat dan memahami terhadap perintah/informasi apa yang diberikan oleh guru. Begitupun hasil karya, merupakan penilaian yang dilakukan terhadap karya anak yang dihasilkan dari buah pikir anak yang dituangkan dalam karya nyata (PERMENDIKBUD 146 Tahun 2014). Contoh karya nyata seperti pekerjaan tangan, karya seni atau tampilan anak seperti gambar, lukisan, hasil kolase, coretan, tari, bangunan balok, dan lainnya. Artinya, buah pikir yang dimiliki anak dikarenakan anak memiliki pemahaman terhadap suatu hal sesuai dengan imajinasinya. Maka dari itu, unjuk kerja dan hasil karja juga dapat digunakan dalam melihat sejauh mana anak mengingat dan memahami.

\subsection{Metode Penilaian Tes}

Tes merupakan serangkaian tugas atau perintah yang diberikan kepada peserta didik untuk dikerjakan guna bagi guru untuk mendapatkan informasi mengenai sejauh mana kemampuan peserta didik terhadap suatu aspek. Menurut Arifin (2012: 7), didalam tes prestasi belajar peserta didik, aspek perilaku yang hendak diukur ialah tingkat kemampuan peserta didik dalam menguasai materi pembelajaran yang telah disampaikan.

Rumusan yang disampaikan diatas memperhatikan beberapa unsur penting dalam penilaian tes, yaitu (Nurlaili 2018: 19): Pertama, tes merupakan suatu cara atau teknik yang disusun secara sistematis dan digunakan dalam rangka kegiatan 
pengukuran. Kedua, didalam tes terdapat berbagai pertanyaan- pertanyaan atau serangkaian tugas yang harus dijawab oleh peserta didik. Ketiga, tes digunakan untuk mengukur suatu aspek perilaku peserta didik. Keempat, hasil tes peserta didik harus diberi skor dan nilai.

\subsubsection{Tes Tertulis}

Betuk tes tertulis ini ialah berupa soal-soal yang harus dijawab peserta didik dengan memberikan jawaban tertulis. Secara umum jenis tes ini dibagi menjadi dua yaitu tes objektif yang berbentuk pilihan ganda, jawaban singkat atau isian, benar salah, dan bentuk menjodohkan antara kedua hal. Selanjutnya ada tes uraian yang terbia menjadi tes uraian objektif (penskoran dapat dilakukan secara objektif) dan tes uraian non objektif (penskoran sulit dilakukan secara objektif).

\subsubsection{Tes lisan}

Bentuk tes lisan ini dilakukan dengan memberikan pertanyaan/tanya jawab secara langsung oleh peserta didik. Tes lisan ini dapat menilai langsung kemampuan dan tingkat pengetahuan yang dimiliki peserta didik, sikap, serta kepribadiannya karena dilakukan secara berhadapan langsung secara individu dengan peserta didik. Bagi peserta didik yang kemampuan berfikirnya relative lambat sehingga mengalami kesulitan dalam memahami soal, akan memiliki kemudahan karena bisa langsung untuk diulang pertanyaannya dalam bentuk yang lebih sederhana. Hasil tes lisan ini juga dapat langsung diketahui oleh anak baikbenar atau salahya suatu jawaban yang diutarakannya.

\subsubsection{Tes perbuatan}

Bentuk tes perbuatan ini berupa sebuah penugasan yang pelaksanaannya dilakukan peserta didik dengan perilaku atau unjuk kerja. Penyampaian tugasnya baik berupa tulisan ataupun lisan oleh guru. 
Tabel 2. Bentuk Instrumen Teknik Penilaian Tes

\begin{tabular}{|l|l|}
\hline \multicolumn{1}{|c|}{ Teknik Penilaian } & \multicolumn{1}{c|}{ Bentuk Istrumen } \\
\hline Tes Tulisan & $\begin{array}{l}\text { Tes pilihan: pilihan ganda, benar salah, } \\
\text { menjodohkan, dll } \\
\text { Tes isian: isian singkat dan uraian }\end{array}$ \\
\hline \multirow{3}{*}{ Tes Lisan } & $\begin{array}{l}\text { Tes identifikasi } \\
\text { Tes simulasi } \\
\text { Tes uji petik kinerja }\end{array}$ \\
\hline Tes Perbuatan & Pekerjaan rumah \\
& Projek \\
\hline
\end{tabular}

Menurut Anita (2015: 65) metode tes didalam Pendidikan Anak Usia Dini sangat jarang digunakan. Akan tetapi pada dasarnya metode tes pada Pendidikan Anak Usia Dini tetap digunakan, hanya saja dalam tingkat dan cara yang berbeda. Metode tes yang digunakan anak usia dini harus sesuai dengan kemampuan anak, misalnya pada kemampuan mengenal alat-alat pekerjaan. Kemampuan mengenal alat pekerjaan dilakukan dengan cara lembar kerja mencocokkan/menjodohkan, dimana anak akan mencocokkan/menjodohkan dengan menarik garis yang sesuai antara gambar pekerjaan dengan gambar alat pekerjaan. Lembar kerja yang diisi anak akan mendapatkan informasi bagi guru sejauh mana pengetahuan yang dimiliki oleh anak mengenai alat-alat pekerjaan. Sesuai yang dipaparkan Arifin (2012: 160) bahwa salah satu pengembangan bentuk tes yaitu menjodohkan yang sangat efektif untuk menjadi pengukur kemampuan peserta didik dalam mengidentifikasi hubungan sederhana dan kemampuan menghubungkan kemampuan antara dua hal.

Beberapa teknik penilaian yang digunakan oleh TK Al-Fadhillah, teknik penilaian tes lisan/percakapan sangat sering digunakan guru dalam melihat ketercapaian aspek pengetahuan pada anak. Metode percakapan yang digunakan ini memiliki kepentingan dalam aspek pengetahuan yang sesuai seperti dipaparkan oleh Ifat Fatimah Zahro (2015) didalam jurnalnya yang berjudul "Penilaian Pembelajaran 
Anak Usia Dini". Teknik percakapan ini sangat diperlukan untuk mengumpulkan informasi mengenai sejauh mana pengetahuan atau penalaran anak mengenai sesuatu hal.

Tes lisan yang terdapat didalam bentuk penilaian tes dan percakapan yang terdapat didalam bentuk penilaian nontes bisa dikatakan bentuk yang sama. Dimana pada tes lisan, guru menuntut jawaban dari peserta didik dalam bentuk lisan (Arifin 2012: 165). Peserta didik memiliki kesempatan untuk memberikan jawaban menggunakan kemampuan berbahasanya. Begitupun pada pengertian percakapan, dimana guru menuntut jawaban atau respon peserta didik melalui kata-kata. Akan tetapi penilaian percakapan pada metode nontes bisa dilakukan dari guru terhadap anak atau anak dengan anak (Nurlaili 2018: 165), sedangkan pada tes keseluruhan guru memegang kendali terhadap apa yang akan ditanya. Artinya, selain berguna bagi guru dalam menilai pengetahuan dan penalaran anak mengenai suatu hal, metode penilaian melalui tes lisan/percakapan ini juga berperan dalam mengembangkan kemampuan berbahasan anak.

Sebuah penelitian yang dilakukan Gusmeta dkk (2015) dengan judul penelitian "Pengaruh Permainan Dore Terhadap Kemampuan Berbicara Anak Di Taman Kanak-Kanak Dharma Wanita Universitas Negeri Padang”. Permainan dore ini dimodifikasi oleh peneliti dengan cara bermain yaitu setiap gambaran persegi empat dore, terdapat gambar-gambar yang familiar dengan anak. Gambar tersebut untuk anak bisa menjelaskan sesuai dengan pikiran atau ide anak. Guru akan memberikan pertanyaan mengenai gambar tersebut. Cara bermain yang dipaparkan tersebut dilakukannya pengumpulan data menggunakan tes lisan (terdapat 9 pertanyaan mengenai gambar) dengan menggunakan metode penelitian Quasy eksperimental, adanya kelas eksperimen yang menggunakan permainan dore dan kelas control yang menggunakan permainan kotak pos. Ketika penelitian dilakukan anak sangat antusias menjawab pertanyaan dari guru dan memaparkan apa yang diketahui dari gambar yang ia dapatkan. Hasil penelitian memaparkan permainan ini yang dilakukan 
menggunakan tes lisan pada anak, dapat meningkatkan kemampuan berbicara anak dibandingkan dengan permainan pada kelas kontrol. Penelitian tersebut menggambarkan bahwa jawaban atau penjelasan yang diberikan anak melalui tes lisan pada permainan dore tidak hanya meningkatkan aspek pengetahuan anak, melainkan kemampuan bahasa anak juga ikut meningkat. Hal ini dikarenakan ketika anak diberi pertanyaan oleh guru, anak mampu memahami pertanyaan tersebut dan mengingat kembali apa yang sesuai dengan gambar tersebut ini termasuk dalam meningkatkan aspek pengetahuan. Setelah anak memahami dan mengingat apa yang sesuai dengan gambar, anak memaparkan menggunakan kemampuan bahasanya, dengan begitu anak melatih kemampuan bahasanya.

Keberhasilan penelitian lain menggunakan tes lisan pada anak usia dini dilakukan oleh Naelul dkk (2016) dengan judul penelitian "Pengaruh Penggunaan Media Gambar Terhadap Kemampuan Berbicara Pada Anak Usia Dini”. Penelitian ini menggunakan teknik pengumpulan data salah satunya yaitu tes lisan terhadap apa yang diketahui anak dari media gambar yang disediakan yang diekpresikan melalui kata-kata. Artinya, setia apa yang diutarakan anak melalui lisannya, itu menggambarkan seberapa besar pengetahuan yang dimiliki anak. Maka dari itu tes lisan menjadi salah satu bentuk penilaian yang tepat dalam mengetahui sejauh mana aspek pengetahuan yang ada pada anak.

\section{KESIMPULAN}

Berdasarkan uraian diatas, penilaian terhadap aspek pengetahuan (KI-3) dilakukan pada setiap aspek perkembangan yang mengacu pada standar tingkat pencapaian perkembangan anak. Setiap aspek perkembang disesuai dengan kompetensi dasar khususnya pada aspek pengetahuan (KI-3) yang nantinya akan dilaporkan pada akhir semester. Pada umumnya, penilaian dibagi menjadi dua jenis yaitu tes dan non tes. Pada TK Al-Fadhillah penilaian terhadap aspek pengetahuan dilakukan melalui teknik nontes yaitu hasil karya, catatan anekdot, dan skala 
penilaian lingkup perkembangan dan metode nontes yaitu tes lisan/percakapan. Hal ini dikarenakan guru dapat langsung melihat sejauh mana pengetahuan atau penalaran anak terhadap sesuatu hal baik secara terstruktur maupun tidak.

Penilaian tes pada pendidikan anak usia dini sering dibantah bahwa tidak bisa digunakan. Akan tetapi pada kenyataannya, selalu ada tes yang digunakan dalam pembelajaran anak usia dini. Hanya saja tes yang diberikan dalam bentuk yang sangat sederhana dan sesuai dengan pembelajaran dan perkembangan anak. Metode tes ini juga sangat bermanfaat bagi penilaian aspek pengetahuan. Sebagai contoh, didalam metode tes, terbagi menjadi tes tulisan, tes lisan, dan tes perbuatan. Pada tes tulisan anak biasanya melakukan kegiatan mencocokkan kedua hal yang berhubungan diatas lembar kerja yang dibagi guru. Selanjutnya pada tes lisan, guru memberikan pertanyaan-pertanyaan secara lisan, dan anak menjawab atau merepon dengan kemampuan bahasanya. Artinya dengan kemampuan komunikasi anak, akan memberi informasi bagi guru dalam menilai sejauh mana pengetahuan anak mengenai hal yang ditanyakan. Terakhir ada tes tindakan, ini dilakukan anak berupa unjuk kerja yang diperintahkan guru dari tertulis atau secara lisan. Dari semua pertanyaan yang

dipaparkan dalam metode penilaian tes, maka kita akan melihat sejauh mana pemahaman anak mengenai butir- butir pertanyaan yang dipaparkan.

\section{E. DAFTAR PUSTAKA}

Anita Yus, 2015, Penilaian Perkembangan Belajar Anak Taman Kanak-Kanak, Jakarta: Kencana

Arikunto Suharsimi, 2015, Dasar-Dasar Evaluasi Pendidikan, Jakarta: Bumi Aksara

Arifin Zainal, 2012, Evaluasi Pembelajaran, Jakarta: Dirjen Pendidikan Islam Kementrian Agama RI

Asrul, Rusydi Ananda, Rosnita, 2014, Evaluasi Pembelajaran, Bandung: Cita Pustaka Media

Eka damayanti, "Manajemen Penilaian Pendidikan Anak Usia Dini", NANAEKE Indonesian Journal of Early Childhood Education, Vol.1 No.1 Tahun 2018

Elis Ratnawulan \& Rusdiana, Evaluasi Pembelajaran, Bandung: Pustaka Setia

Enah Suminah.dkk, 2015, Pedoman Penilaian Pendidikan Anak Usia Dini, Jakarta:

Dirjen Pendidikan Anak Usia Dini dan Pendidikan Masyaraka 
Gusmeta dkk, "Pengaruh Permainan Dore Terhadap Kemampuan Berbicara Anak Di

Taman Kanak-Kanak Dharma Wanita Universitas Negeri Padang”, Jurnal Pesona PAUD, Tahun 2015, Artikel Skripsi

Hamzah B Uno \& Satria Koni, 2013, Assesment Pembelajaran, Jakarta: Bumi Aksara Hari Setiadi, "Pelaksanaan Penilaian Pada Kurikulum 2013", Jurnal Penelitian dan Evaluasi Pendidikan, Vol.20, No.2, Tahun 2016

Ifat Fatimah Zahro, "Penilaian Dalam Pembelajaran Anak Usia Dini", Jurnal Tunas Siliwangi, Vol.1 No.1 Tahun 2015

Imam \& Anggarini, "Taksonomi Bloom-Revisi Ranah Kognitif: Kerangka Landasan Untuk Pembelajaran, Pengajaran, dan Penilaian”, Jurnal Pendidikan, Vol 2, No 02 tahun 2012

Naelul, "Pengaruh Penggunaan Media Gambar Terhadap Kemampuann Berbicara Anak Usia Dini”, Jurnal Infantia, Vol.4 No.2, Tahun 2016

Nurlaili, 2018, Evaluasi Pembelajaran AUD, Prodi PIAUD FITK UIN Sumatera Utara, DIKTAT

PERMENDIKBUD 146 Tahun 2014

Suwandi Sarwiji, 2011, Model-Model Assesmen Dalam Pembelajaran, Surakarta: Yuma Pustaka

Suyadi, "Perencanaan dan Asesmen Perkembangan Pada Anak Usia Dini (Studi Kasus pada Lembaga Pendidikan Anak Usia Dini (PAUD/TK/RA) di Daerah Istimewa Yogyakarta)", Jurnal Golden Age, Vol.1 No.1 Tahun 2016

Yuli Kwartolo, "Multiple Intelligences dan Implementasinya dalam Taksonomi Bloom", Jurnal Pendidikan Penabur, No 18, Tahun ke 11, 2012 
Volume 1 No 1 2019, J-Sanak_Jurnal Kajian Anak | 110 